Cardiology in the Young (2017), 27, 1504-1521 C Cambridge University Press, 2017. This is an Open Access article, distributed under the terms of the Creative Commons Attribution licence (http://creativecommons.org/licenses/by/4.0/), which permits unrestricted re-use, distribution, and reproduction in any medium, provided the original work is properly cited.

doi:10.1017/S1047951117000609

\title{
CHD and respiratory syncytial virus: global expert exchange recommendations
}

Robert M. R. Tulloh, ${ }^{1}$ Constancio Medrano-Lopez, ${ }^{2}$ Paul A. Checchia, ${ }^{3}$ Claudia Stapper,${ }^{4}$ Naokata Sumitomo, ${ }^{5}$ Matthias Gorenflo, ${ }^{6}$ Eun Jung Bae, ${ }^{7}$ Antonio Juanico, ${ }^{8}$ Juan M. Gil-Jaurena, ${ }^{9}$ Mei-Hwan Wu, ${ }^{10}$ Talal Farha, ${ }^{11}$ Ali Dodge-Khatami, ${ }^{12}$ Rocky Tsang, ${ }^{13}$ Gerard Notario, ${ }^{14}$ Colleen Wegzyn ${ }^{14}$

${ }^{1}$ Paediatric Cardiology, Bristol Royal Hospital for Children, Bristol, United Kingdom; ${ }^{2}$ Pediatric Cardiology, Hospital General Universitario Gregorio Marañón, Madrid, Spain; ${ }^{3}$ Cardiovascular Intensive Care Unit, Texas Children's Hospital and Sections of Pediatric Critical Care Medicine and Cardiology, Baylor College of Medicine, Houston Texas, United States of America; ${ }^{4}$ Pediatric Cardiology, Congenital Heart Institute, Fundación Cardioinfantil, Bogotá, Colombia; ${ }^{5}$ Pediatric Cardiology, Saitama Medical University International Medical Center, Saitama, Japan; ${ }^{6}$ Pädiatrische Kardiologie und Angeborene Herzfebler, Zentrum für Kinder- und Jugendmedizin Universitätsklinikum Heidelberg, Heidelberg, Germany; ${ }^{7}$ Pediatrics, Seoul National University College of Medicine, Seoul, South Korea; ${ }^{8}$ Cardiología Pediátrica, Instituto Nacional de Cardiología Ignacio Chávez, Mexico City, Mexico; ${ }^{9}$ Pediatric Cardiac Surgery, Hospital General Universitario Gregorio Marañon, Madrid, Spain; ${ }^{10}$ Department of Pediatrics, National Taiwan University Hospital, Taipei, Taiwan; ${ }^{11}$ Paediatrics, Paediatric Cardiology, Farba Children Clinics, Dubai, United Arab Emirates; ${ }^{12}$ Division of Pediatric and Congenital Heart Surgery, University of Mississippi Medical Center, Jackson, Mississippi; ${ }^{33}$ Pediatric Cardiology, Children's Hospital of Philadelphia, Philadelphia, Pennsylvania;

${ }^{14}$ Neonatology, AbbVie Inc., North Chicago, Illinois, United States of America

Abstract Background: Palivizumab is the standard immunoprophylaxis against serious disease due to respiratory syncytial virus infection. Current evidence-based prophylaxis guidelines may not address certain children with CHD within specific high-risk groups or clinical/management settings. Methods: An international steering committee of clinicians with expertise in paediatric heart disease identified key questions concerning palivizumab administration; in collaboration with an additional international expert faculty, evidence-based recommendations were formulated using a quasi-Delphi consensus methodology. Results: Palivizumab prophylaxis was recommended for children with the following conditions: $<2$ years with unoperated haemodynamically significant $\mathrm{CHD}$, who are cyanotic, who have pulmonary hypertension, or symptomatic airway abnormalities; $<1$ year with cardiomyopathies requiring treatment; in the 1st year of life with surgically operated CHD with haemodynamically significant residual problems or aged 1-2 years up to 6 months postoperatively; and on heart transplant waiting lists or in their 1st year after heart transplant. Unanimous consensus was not reached for use of immunoprophylaxis in children with asymptomatic CHD and other co-morbid factors such as arrhythmias, Down syndrome, or immunodeficiency, or during a nosocomial outbreak. Challenges to effective immunoprophylaxis included the following: multidisciplinary variations in identifying candidates with CHD and prophylaxis compliance; limited awareness of severe disease risks/burden; and limited knowledge of respiratory syncytial virus seasonal patterns in subtropical/tropical regions. Conclusion: Evidence-based immunoprophylaxis recommendations were formulated for subgroups of children with CHD, but more data are needed to guide use in tropical/subtropical countries and in children with certain co-morbidities.

Keywords: CHD; prophylaxis; palivizumab; respiratory syncytial virus

Received: 2 September 2016; Accepted: 27 February 2017; First published online: 16 June 2017

Correspondence to: Professor R. M. R. Tulloh, MA, DM, FRCPCH, Consultant in Paediatric Cardiology and Pulmonary Hypertension, Department of Congenital Heart Disease, Bristol Royal Hospital for Children, Paul O'Gorman Building, Upper Maudlin Street, Bristol, BS2 8BJ, United Kingdom, Tel: +44 117 342 8176; Fax: +44 1173428 857; E-mail: Robert.Tulloh@Bristol.ac.uk 
$\mathrm{R}$ ESPIRATORY SYNCYTIAL VIRUS IS A COMMON PATHOgen affecting most children by the age of 2 years. ${ }^{1}$ Respiratory syncytial virus infection is considered among the most important identified causes of post-neonatal lower respiratory infection. ${ }^{2}$ On the basis of 2010 global estimates, lower respiratory tract infection causes $20 \%$ of the $\sim 2$ million deaths per year in infants aged 28 days to 1 year. $^{2}$ The rate of hospitalisation for disease due to respiratory syncytial virus is subject to seasonal and local geographic variation but has been reported to be $\sim 5$ for every 1000 children younger than 24 months. ${ }^{3}$ Infants with CHD are particularly susceptible to adverse outcomes, and respiratory syncytial virus-related hospitalisation in this patient population is associated with a high risk of serious or fatal disease. ${ }^{4}$ For children with $\mathrm{CHD}$, serious disease due to respiratory syncytial virus infection can be associated with both pulmonary - for example pulmonary hypertension or need for prolonged mechanical ventilation - or cardiac complications - for example, sinoatrial block - which could add further challenges to the management of any underlying heart failure conditions, including causing delays to planned corrective surgeries or increasing morbidity postoperatively. ${ }^{5,6}$ In patients with CHD, the increased risk of severe disease due to respiratory syncytial virus infection may be related to multiple physiological factors including baseline compromised cardiorespiratory function, changed mechanisms of pulmonary regulation, ventilation-perfusion mismatch, and potential cyanosis and/or pulmonary hypertension. ${ }^{7}$ A study by Boyce et $\mathrm{al}^{8}$ has identified hospitalisation rates of up to $12 \%$ in infants with CHD. Palivizumab is the regulatory-approved, standard immunoprophylaxis against serious disease due to respiratory syncytial virus infection in high-risk infants and young children in the absence of an available vaccine. In a pivotal randomised clinical trial of children $\leqslant 24$ months of age with documented haemodynamically significant $\mathrm{CHD}$, those who received palivizumab prophylaxis had a $45 \%$ relative reduction $(95 \%$ confidence interval: 23,67$)$ in respiratory syncytial virus hospitalisations versus placebo. ${ }^{\text {? }}$

Current evidence-based respiratory syncytial virus disease management guidelines for use of immunoprophylaxis against serious disease due to respiratory syncytial virus infection may not adequately address some children with CHD who fall within specific high-risk clinical groups or certain clinical or management settings. Recommendations for the use of immunoprophylaxis including for children with CHD have been published by expert groups from a number of countries including Canada, ${ }_{10}$ France, ${ }^{11}$ Germany, ${ }^{12}$ Japan, ${ }^{13}$ Italy, ${ }^{14}$ Mexico, ${ }^{15}$ Spain, ${ }^{15}$ Taiwan, ${ }^{16}$ the United Kingdom, ${ }^{17}$ and the United States of America ${ }^{18,19}$ (Table 1). In 2005, a consensus statement from representatives of multiple European countries was published; ${ }^{21}$ however, among these guidelines from geographically diverse regions, there are variations in the CHD subpopulations that are considered candidates for immunoprophylaxis. These differences may be attributed to the clinical evidence available at the time when the guidelines were published and regional variations in healthcare practices, provisions, for example, resource management procedures for delivery of healthcare services, and funding. Healthcare providers may also face other challenges in effective immunoprophylaxis decisions, such as no guidelines for some geographic areas and a lack of a clear definition of haemodynamically significant CHD. Furthermore, although various economic evaluations exist, ${ }^{22-25}$ clinicians must appropriately interpret and apply these findings to individual cases encountered in daily practice.

To aid healthcare providers practising in diverse geographic settings in treatment decisions for immunoprophylaxis by supplementing available information - for example, international and country-specific guidelines and approved prescribing information - with new evidence and greater clinical experience, an international steering committee of clinicians with expertise in paediatric CHD collaborated to discuss global variations in the use of palivizumab immunoprophylaxis against serious disease due to respiratory syncytial virus infection. A particular focus of the steering committee was on clinical situations that are not fully described within current guidelines. By gathering input from an additional international expert faculty, recommendations that are supported by current literature data and experience from global clinical practice were formulated.

\section{Materials and methods}

\section{Steering committee and faculty}

An international steering committee of five senior paediatric cardiology clinicians and additional faculty of eight international experts - for example, paediatric cardiologists, intensive care specialists, and cardiac surgeons - collaborated to create the recommendations (Fig 1a). The group was co-chaired by two senior cardiologists - R.M.R.T. and C.M.-L. - and each member was equally responsible for input into the final recommendations. To ensure that the group's recommendations would be widely applicable, the steering committee recommended international experts from diverse geographical locations where serious disease due to respiratory syncytial virus infection was a concern and palivizumab was available. 
Table 1. International and country-specific guidelines related to immunoprophylaxis against serious disease due to RSV infection.

\begin{tabular}{ll}
\hline Country & Guideline \\
\hline Canada & $\begin{array}{c}\text { Position Statement of the Canadian } \\
\text { Paediatric Society }\end{array}$ \\
Germany & $\begin{array}{c}\text { The Deutsche Gesellschaft für } \\
\text { Pädiatrische Kardiologie } \\
\text { guidelines }\end{array}$ \\
The Japanese Society of Paediatric \\
Jardiology and Cardiac Surgery \\
guidelines
\end{tabular}

Key groups of children recommended for immunoprophylaxis

Children aged $<12$ months with hsCHD or CLD, requiring ongoing diuretics, bronchodilators, steroids, or supplemental oxygen, at the start of RSV season Children aged $<24$ months who are on home oxygen, with prolonged hospitalisation for pulmonary disease or severely immunocompromised

No routine immunoprophylaxis in children with immunodeficiencies, Down syndrome, or chronic pulmonary disease other than CLD

Children with CHD at the start of RSV season:

Aged $<12$ months are high risk

Aged 12-24 months are moderate risk

Children with CHD aged $\leqslant 24$ months at the start of RSV season with $\geqslant 1$ of the following: hsHD

No surgical intervention or hs problems after surgery, corrective or palliative Pulmonary hypertension, (before or after cardiac surgery)

Expected surgical procedures (cardiac or non-cardiac surgery) or cardiac catheterisation Haemodynamically insignificant CHD complicated by respiratory disease

Children with CHD aged $\leqslant 24$ months at the start of RSV season with no significant signs/ symptoms or complete cure of $\mathrm{CHD}$, but with the following:

Chromosomal or genetic abnormalities including Trisomy 21 (Down syndrome), other trisomy, or 22q11.2 deletion syndrome

Other congenital anomalies and respiratory system abnormalities (functional/organic)

Children aged $\leqslant 24$ months at the start of RSV season with hs cardiomyopathy, or

arrhythmia, which may be complicated by RSV infection

Italy Revised recommendations concerning palivizumab prophylaxis for respiratory syncytial virus ${ }^{14}$

Mexico and The Spanish Society of Paediatric Spain Cardiology and Congenital Heart Disease guidelines (followed in Spain and in Mexico) based on the Spanish clinical consensus document ${ }^{15}$

Children aged $<12$ months with hsCHD at the start of RSV season with the following: Cyanotic HD (unoperated or palliated), based on the haemodynamic status of the patient (paediatric cardiologist judgement)

Acyanotic heart disease on CHF therapy and scheduled for surgery

Moderate-to-severe pulmonary hypertension

Infants with surgically repaired CHD but still requiring therapy for CHF

Infants suffering from congestive cardiomyopathy or treated with anti-congestive drugs Infants on waiting list for heart transplantation or in the post-transplantation period

Consider immunoprophylaxis in children aged $<24$ months receiving a heart transplant during RSV season

Consider immunoprophylaxis in children with Down syndrome without HD, based on clinical condition

Children aged $\leqslant 24$ months with CHD during RSV season with the following:

Non-corrected significant HD and haemodynamic impact (i.e., hsCHD)

Partially corrected complex CHD (palliative intervention) exhibiting haemodynamic involvement

Corrected CHD exhibiting residual lesions with haemodynamic impact

Corrected CHD with a history of severe pulmonary complications and/or who have required prolonged mechanical ventilation

Corrected CHD without residual lesions but who still exhibit haemodynamic involvement in the immediate postoperative period

Children aged $\leqslant 24$ months during RSV season with the following:

Pulmonary hypertension (primary or secondary; moderate or severe)

Cardiomyopathies requiring medical treatment

Arrhythmias (severe, relapsing arrhythmia with current or previous haemodynamic impact needing chronic medication)

With a heart transplant or awaiting heart transplantation

Children with associated risk factors (i.e., aged $<12$ months with 22q11.2 deletion

syndrome, or aged $\leqslant 24$ months for Down syndrome or immunodeficiency) during RSV season with the following:

Operated CHD, with or without residual defects and no haemodynamic impact (i.e., mitral cleft with mild insufficiency)

Non-operated mild CHD and with no haemodynamic impact (i.e., silent ductus arteriosus, small interatrial shunt, restrictive interventricular shunting)

Korea Korean Ministry of Health Reimbursement Guidelines ${ }^{20}$

Children aged $<1$ year with hsCHD at the start of RSV season and $\geqslant 1$ of the following: Receiving medication to control CHF

With moderate-to-severe pulmonary arterial hypertension

With cyanotic HD 
Table 1. Continued

\begin{tabular}{|c|c|c|}
\hline Country & Guideline & Key groups of children recommended for immunoprophylaxis \\
\hline Taiwan & $\begin{array}{l}\text { Taiwanese guidelines from the } \\
\text { Society of Paediatric Cardiology } \\
\text { and the Society of Neonatology }\end{array}$ & $\begin{array}{l}\text { Children aged }<1 \text { year with hsCHD: } \\
\text { Cyanotic CHD } \\
\text { Non-cyanotic CHD or cardiomyopathy; either condition combined with HF and two of } \\
\text { the following: (1) failure to thrive (weight }<\text { third percentile on a standard growth } \\
\text { chart), ( } 2 \text { ) significantly enlarged heart, or }(3) \text { use of } \geqslant 2 \text { anti-CHF medicines (to control } \\
\text { symptoms) or cyanotic CHD (with cyanosis or HF symptoms, before or after corrective } \\
\text { surgery) }\end{array}$ \\
\hline $\begin{array}{l}\text { United } \\
\text { Kingdom }\end{array}$ & $\begin{array}{l}\text { The British Congenital Cardiac } \\
\text { Association and Joint Committee } \\
\text { on Vaccination and Immunisation } \\
\text { guidelines }^{17}\end{array}$ & $\begin{array}{l}\text { Infants aged }<1 \text { year with documented hsCHD (e.g., increased pulmonary blood flow } \\
\text { conditions, cyanotic HD, pulmonary venous congestion, pulmonary hypertension, long- } \\
\text { term pulmonary complications, unoperated or partially corrected complex CHD) } \\
\text { Infants with residual hsCHD following intervention (medical or surgical) } \\
\text { Infants with pulmonary hypertension } \\
\text { Infants receiving treatment for cardiomyopathy } \\
\text { Consider immunoprophylaxis in infants aged }<1 \text { year with CHD with expected need for } \\
\text { hospital admission (medical or surgical) } \\
\text { Immunoprophylaxis may be indicated for certain children aged }>1 \text { year, with complex } \\
\text { cardiac disease (based on clinician judgement) }\end{array}$ \\
\hline $\begin{array}{l}\text { United States } \\
\text { of America }\end{array}$ & $\begin{array}{l}\text { The American Academy of } \\
\text { Pediatrics guidance/updated } \\
\text { guidance on RSV prophylaxis }\end{array}$ & $\begin{array}{l}\text { Children aged }<12 \text { months with hsCHD (e.g., acyanotic HD receiving medication for } \\
\text { CHF and requiring surgery, moderate-to-severe pulmonary hypertension) } \\
\text { Consider immunoprophylaxis in profoundly immunocompromised children aged } \\
<2 \text { years during RSV season } \\
\text { Routine immunoprophylaxis in children with Down syndrome only with qualifying HD, } \\
\text { CLD, airway clearance issues, or prematurity ( }<29 \text { weeks, } 0 \text { days gestation) }\end{array}$ \\
\hline
\end{tabular}

$\mathrm{CHF}=$ chronic heart failure; $\mathrm{CLD}=$ chronic lung disease; $\mathrm{HD}=$ heart disease; $\mathrm{HF}=$ heart failure; $\mathrm{hs}=$ haemodynamically significant hs $\mathrm{CHD}=$ haemodynamically significant $\mathrm{CHD} ; \mathrm{RSV}=$ respiratory syncytial virus

\section{Consensus process}

The Delphi method for consensus is a wellestablished process whereby a questionnaire is presented to a panel of experts to elicit their opinions, and then multiple iterations of review and refinement are used to build group agreement. ${ }^{20,26}$ The classical Delphi method allows the respondents to remain anonymous to both the central reviewer(s) and the other respondents. A quasi-Delphi consensus methodology - for example a non-anonymous smaller panel and qualitative analyses of the data ${ }^{26}$ - was used to develop recommendations (process depicted in Fig 1b). On the basis of questions initially developed by the steering committee, the additional faculty developed recommendations, which were finalised by the steering committee. The process included both face-to-face and online meetings. The roles of the co-chairmen included suggestion of areas of continuing debate and evidence gaps regarding immunoprophylaxis in patients with CHD, choice of the final items, and final presentation of the agreement. After a review of previous guidelines (Table 1), the focus was on clinical controversies, such as unanswered questions and issues with lack of clarity, identification of unmet needs, and preventive and management strategies for special subgroups of the most vulnerable children with CHD at risk of serious respiratory syncytial virus disease. Once the key questions were developed by the steering committee, the international expert faculty participated in the process by providing answers via an online digital platform. Each participant reviewed all comments or answers and uploaded published evidence in support of their answer or opinion. The supporting evidence for the recommendation - that is, published literature - was then independently verified by other members of the faculty and the steering committee. The consolidated answers were summarised into recommendations and reviewed by the steering committee. Agreement or disagreement with draft clinical recommendations and order of clinical priority were determined by the eight faculty members. In cases of disagreement with the draft wording, the chairman/steering committee member contacted the faculty member to understand and clarify the issue. In collaboration, the draft wording was then amended to the member's satisfaction and agreement. Strength of evidence grades and levels - was assessed as per standard practice (Fig 2). ${ }^{27}$ Haemodynamically significant CHD was defined as cyanotic stratum, unoperated or partially corrected by cardiac surgery or interventional catheterisation, hypercyanotic episode, receiving cardiac medications, congestive heart failure, pulmonary hypertension, and increased pulmonary blood flow according to a previous study. ${ }^{9}$ 
(a)

\begin{tabular}{|l|l|}
\hline Steering committee members & $\begin{array}{l}\text { Faculty members } \\
\text { Colombia: Dr Claudia Stapper }\end{array}$ \\
Japan: Professor Naokata Sumitomo & Korea: Professor Eun Jung Bae \\
Spain: Professor Constancio Medrano-Lopez (co-chair) & Mexico: Dr Antonio Juanico \\
United Kingdom: Professor Robert Tulloh (co-chair) & Spain: Dr Juan Miguel Gil-Jaurena \\
United States: Dr Paul Checchia & Taiwan: Professor Mei-Hwan Wu \\
& United Arab Emirates: Dr Talal Farha \\
& United States: Professor Ali Dodge-Khatami \\
& \multicolumn{1}{|c}{ Dr. Rocky Tsang } \\
\hline
\end{tabular}

(b)

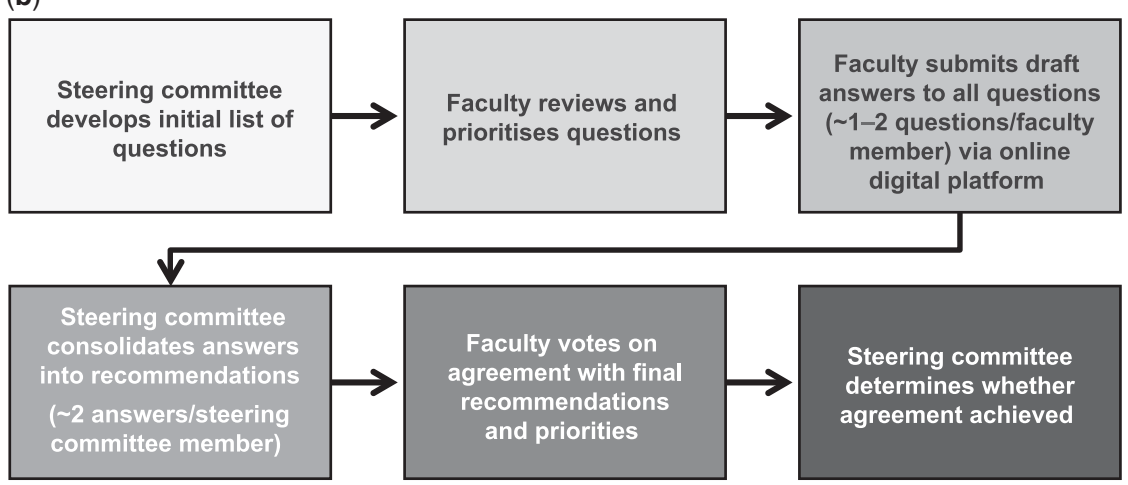

Figure 1.

(a) Respiratory syncytial virus Global Expert Steering Committee and Faculty Members; (b) algorithm for the step-by-step process.

\section{Results}

For each of the 14 questions developed by the steering committee, the consensus recommendations of the faculty are provided, along with the evidence grade/level and key supportive references (Table 2).

Question 1: Who should be involved in developing the standard of care for the use of palivizumab prophylaxis in children with CHD?

Recommendation: Paediatric medical professionals, professional medical societies/associations, government health departments, and other agencies relevant to the particular country should be involved in setting standards of care for the use of palivizumab prophylaxis in children with CHD.

Voting Results: agree/disagree 8-0; Level of Evidence: $1 \mathrm{a}^{18,19,28}$

The faculty agreed (8-0) that determining standards of care for the use of immunoprophylaxis against serious disease caused by respiratory syncytial virus infection in children with CHD should involve a comprehensive multidisciplinary approach, including paediatric medical professionals, professional medical societies/associations, government health departments, and other relevant agencies. Paediatric medical professionals, including cardiologists, cardiac surgeons, infectious diseases specialists, intensive care specialists, and neonatologists, should be most involved in contributing to this process; however, other colleagues, such as epidemiologists, general paediatricians, and primary care physicians, may provide additional support. Professional medical societies or associations - for example, the American Academy of Pediatrics and the British Congenital Cardiac Association - along with national guideline groups and health authorities - were identified as additional stakeholders in standard of care development. Furthermore, it was recommended that government entities - for example, health departments and ministries of health - and other agencies/groups for example, funding bodies, regulators, and parent associations - should also be engaged in the process to seek comprehensive input.

Question 2:

(A) Who are the key decision makers of the need for palivizumab prophylaxis in children with CHD already in hospital?

(B) Who are the key decision makers of the need for palivizumab prophylaxis in children with CHD outside hospitals?

Recommendation: A paediatric cardiologist should make the decision for palivizumab prophylaxis in children with CHD whether in the hospital or in the community.

Voting Results: agree/disagree 8-0; Evidence Grade/Level: Not assigned 


\begin{tabular}{|c|c|c|c|c|c|}
\hline Question & $\begin{array}{l}\text { Step } 1 \\
\left(\text { Level } 1^{\star}\right)\end{array}$ & $\begin{array}{l}\text { Step } 2 \\
\text { (Level 2*) }\end{array}$ & \begin{tabular}{|l} 
Step 3 \\
(Level 3*)
\end{tabular} & $\begin{array}{l}\text { Step } 4 \\
\left(\text { Level } 4^{*}\right)\end{array}$ & $\begin{array}{l}\text { Step } 5 \\
\text { (Level 5) }\end{array}$ \\
\hline $\begin{array}{l}\text { How common is the } \\
\text { problem? }\end{array}$ & $\begin{array}{l}\text { Local and current random sample } \\
\text { surveys (or censuses) }\end{array}$ & $\begin{array}{l}\text { Systematic review of surveys } \\
\text { that allow matching to local } \\
\text { circumstances }^{\dagger}\end{array}$ & Local non-random sample $^{\dagger}$ & Case-series $^{\dagger}$ & $\mathrm{n} / \mathrm{a}$ \\
\hline $\begin{array}{l}\text { Is this diagnostic or } \\
\text { monitoring test } \\
\text { accurate? } \\
\text { (Diagnosis) }\end{array}$ & $\begin{array}{l}\text { Systematic review of } \\
\text { cross sectional studies with } \\
\text { consistently applied reference } \\
\text { standard and blinding }\end{array}$ & $\begin{array}{l}\text { Individual cross sectional } \\
\text { studies with consistently } \\
\text { applied reference standard } \\
\text { and blinding }\end{array}$ & $\begin{array}{l}\text { Non-consecutive studies, or studies without } \\
\text { consistently applied reference standards }{ }^{\dagger}\end{array}$ & $\begin{array}{l}\text { Case-control studies, or } \\
\text { "poor or non-independent } \\
\text { reference standard }\end{array}$ & $\begin{array}{l}\text { Mechanism-based } \\
\text { reasoning }\end{array}$ \\
\hline $\begin{array}{l}\text { What will happen if } \\
\text { we do not add a } \\
\text { therapy? } \\
\text { (Prognosis) } \\
\end{array}$ & $\begin{array}{l}\text { Systematic review of } \\
\text { inception cohort studies }\end{array}$ & Inception cohort studies & Cohort study or control arm of randomized trial ${ }^{*}$ & \begin{tabular}{|l|} 
Case-series or \\
case-control studies, \\
or poor quality prognostic \\
cohort study ${ }^{\dagger}$
\end{tabular} & $\mathrm{n} / \mathrm{a}$ \\
\hline $\begin{array}{l}\text { Does this intervention } \\
\text { help? } \\
\text { (Treatment Benefits) } \\
\end{array}$ & $\begin{array}{l}\text { Systematic review of randomized } \\
\text { trials or } \mathrm{n} \text {-of- } 1 \text { trials }\end{array}$ & \begin{tabular}{|l|} 
Randomized trial or \\
observational study with \\
dramatic effect
\end{tabular} & $\begin{array}{l}\text { Non-randomized controlled cohort/ } \\
\text { follow-up study }\end{array}$ & $\begin{array}{l}\text { Case-series, case-control } \\
\text { studies, or historically } \\
\text { controlled studies }\end{array}$ & $\begin{array}{l}\text { Mechanism-based } \\
\text { reasoning }\end{array}$ \\
\hline $\begin{array}{l}\text { What are the } \\
\text { COMMON harms? } \\
\text { (Treatment Harms) }\end{array}$ & $\begin{array}{l}\text { Systematic review of randomized } \\
\text { trials, systematic review of nested } \\
\text { case-control studies, n-of- } 1 \text { trial } \\
\text { with the patient you are raising the } \\
\text { question about, or observational } \\
\text { study with dramatic effect }\end{array}$ & $\begin{array}{l}\text { Individual randomized trial or } \\
\text { (exceptionally) observational } \\
\text { study with dramatic effect }\end{array}$ & \multirow[t]{2}{*}{$\begin{array}{l}\text { Non-randomized controlled cohort/follow-up } \\
\text { study (post-marketing surveillance) provided } \\
\text { there are sufficient numbers to rule out a } \\
\text { common harm. (For long-term harms the } \\
\text { duration of follow-up must be sufficient.) }^{\dagger}\end{array}$} & \multirow[t]{2}{*}{$\begin{array}{l}\text { Case-series, case-control, } \\
\text { or historically controlled } \\
\text { studies }^{\dagger}\end{array}$} & \multirow[t]{2}{*}{$\begin{array}{l}\text { Mechanism-based } \\
\text { reasoning }\end{array}$} \\
\hline $\begin{array}{l}\text { What are the RARE } \\
\text { harms? } \\
\text { (Treatment Harms) }\end{array}$ & $\begin{array}{l}\text { Systematic review of randomized } \\
\text { trials or } n \text {-of- } 1 \text { trial }\end{array}$ & \begin{tabular}{|l|} 
Randomized trial or \\
(exceptionally) observational \\
study with dramatic effect
\end{tabular} & & & \\
\hline $\begin{array}{l}\text { Is this (early } \\
\text { detection) test } \\
\text { worthwhile? } \\
\text { (Screening) }\end{array}$ & $\begin{array}{l}\text { Systematic review of randomized } \\
\text { trials }\end{array}$ & Randomized trial & $\begin{array}{l}\text { Non-randomized controlled cohort/ } \\
\text { follow-up study }\end{array}$ & $\begin{array}{l}\text { Case-series, case-control, } \\
\text { or historically controlled } \\
\text { studies }^{\dagger}\end{array}$ & $\begin{array}{l}\text { Mechanism-based } \\
\text { reasoning }\end{array}$ \\
\hline
\end{tabular}

Figure 2.

Oxford Centre for Evidence-Based Medicine 2011 Levels of Evidence. $^{27}$

* Level may be graded down on the basis of study quality, imprecision, indirectness - study patient or problem/intervention/comparison/outcomes (PICO) does not match questions PICO - because of inconsistency between studies or because the absolute effect size is very small. Level may be graded up if there is a large or very large effect size. †As always, a systematic review is generally better than an individual study.

The faculty agreed (8-0) that multiple healthcare professionals will be involved in determining the need for palivizumab prophylaxis in children with CHD, irrespective of the setting - hospital or community. The paediatric cardiologist was identified as the key decision maker responsible for identifying immunoprophylaxis candidates among patients with $\mathrm{CHD}$ and ensuring prophylaxis compliance, although it was recognised that other healthcare specialties may be involved in some situations, varying case by case, hospital to hospital, and/or country to country. Supporting decision makers may include colleagues from cardiac surgery, infectious diseases, intensive care, neonatology, epidemiology, general paediatrics, primary care, nursing, and anaesthesiology. The specialist role of the key decision maker - for example, paediatric cardiologist, paediatrician, neonatologist, or infectious disease specialist - may be affected by various factors including the age of the at-risk infant, location and method of patient presentation to healthcare services, local practices, and individual hospital staffing and departmental policy and standards of care - for example, in smaller hospitals without separate paediatric cardiology departments, neonatologists and paediatricians may be heavily involved in decisions regarding respiratory syncytial virus immunoprophylaxis, including in children with $\mathrm{CHD}$, compared with larger centres with distinct paediatric cardiology departments. In addition, in some geographic regions, including developing countries, no paediatric cardiologist may be available and cardiologists who treat adults may also be responsible for the care of children.

Question 3: Which guidelines do you follow to meet the medical needs of your children with CHD?

Recommendation: Healthcare professionals should refer to appropriate national guidelines to meet the immunoprophylaxis needs of children with CHD.

Voting Results: agree/disagree 8-0; Evidence Grade/Level: $1 \mathrm{a}^{12,13,15-19,29,30}$

The faculty agreed (8-0) that in the absence of global consensus guidelines for immunoprophylaxis for children with CHD, relevant national guidelines should be consulted. Several of the key guidelines identified by the group are listed in Table 1 .

Question 4: Based on the benefit shown and from your own clinical experience, in which children with unoperated CHD do you recommend immunoprophylaxis against serious disease due to respiratory syncytial virus infection?

Recommendation: Children under 2 years of age with unoperated haemodynamically significant $\mathrm{CHD}$ who require medication to manage their congestive heart failure, are cyanotic with oxygen saturations $<85 \%$, who have pulmonary hypertension, or who have symptomatic airway abnormalities should be considered candidates for immunoprophylaxis against serious disease due to respiratory syncytial virus infection.

Voting Results: agree/disagree 7-1; Evidence Grade/Level: 1a ${ }^{12,15,30}$ 
Table 2. Questions and recommendations related to immunoprophylaxis against serious disease due to RSV infection in children with CHD. Question
$\begin{aligned} & \text { 1. Who should be involved in developing } \\ & \text { the standard of care for the use of PVZ }\end{aligned}$ prophylaxis in children with CHD?

2. (A) Who are the key decision makers of the need for PVZ prophylaxis in children with CHD already in hospital?

(B) Who are the key decision makers of the need for PVZ prophylaxis in children with CHD outside hospitals?

3. Which guidelines do you follow to meet the medical needs of your children with $\mathrm{CHD}$ ?

4. Based on the benefit shown and from your own clinical experience, in which children with unoperated? CHD do you recommend immunoprophylaxis against serious disease due to RSV infection?

5. Based on the benefit shown and from your own clinical experience, for which group of children with operated CHD do you recommend immunoprophylaxis against serious disease due to RSV infection?

6. On the basis of the benefit shown and from your own clinical experience, in which children with pulmonary hypertension do you recommend immunoprophylaxis against serious disease due to RSV infection during the RSV risk season? Examples of at-risk populations include children with idiopathic pulmonary hypertension or CHD or chronic lung disease associated with pulmonary hypertension

7. On the basis of the benefit shown and from your own clinical experience, in which children with cardiomyopathies do you recommend immunoprophylaxis against serious disease due to RSV infection during the RSV season?

Recommendation

Paediatric medical professionals, professional medical societies/associations, government health departments, and other agencies relevant to the particular country should be involved in setting standards of care for the use of $\mathrm{PVZ}$ prophylaxis in children with CHD

A paediatric cardiologist should make the decision for PVZ prophylaxis in children with CHD whether in the hospital or in the community

Healthcare professionals should refer to appropriate national guidelines to meet the immunoprophylaxis needs of children with CHD

Children under 2 years of age with unoperated hsCHD who require medication to manage their congestive heart failure, are cyanotic with oxygen saturations $<85 \%$, who have pulmonary hypertension, or who have symptomatic airway abnormalities should be considered candidates for immunoprophylaxis against serious disease due to RSV infection

Immunoprophylaxis against serious disease due to RSV infection is recommended for the 1 st year of life in children with surgically operated, hsCHD with residual defects or for children aged 1-2 years up to 6 months postoperatively or on a case-by-case basis. Administration of a palivizumab dose immediately after operations involving cardiopulmonary bypass should be considered because of observed decreases in serum palivizumab levels to non-protective levels

All children younger than 2 years being treated (e.g., with pulmonary vasodilators, oxygen, diuretics, or anticoagulants $^{31}$ ) for idiopathic pulmonary arterial hypertension (defined as a resting mean pulmonary artery pressure $>25 \mathrm{mmHg}$ beyond the first few months of life ${ }^{31}$ ) or with pulmonary hypertension associated with CHD or secondary to cardiomyopathy should receive immunoprophylaxis against serious disease due to RSV infection

We recommend that children younger than 1 year with cardiomyopathies requiring medical treatment, including congestive heart failure therapy and oxygen support, are candidates for immunoprophylaxis against serious disease due to RSV infection
Voting results

(agree/disagree)

Level of evidence

$8-0$

$1 a^{18,19,28}$

8-0

Not assigned

$1 a^{12,13,15-19,29,30}$

$7-1$

$1 \mathrm{a}^{12,15,30}$

$1 \mathrm{a} ; 1 \mathrm{~b}^{9,18,19}$

$1 \mathrm{a} ; 1 \mathrm{~b}^{4,11,15,18,32,33}$ 
Table 2. Continued

\begin{tabular}{l} 
Question \\
\hline 8. Based on the benefit shown and from \\
your own clinical experience, in which \\
children with arrhythmias (including \\
Brugada or long QT syndrome) do you \\
recommend immunoprophylaxis \\
against serious disease due to RSV \\
infection?
\end{tabular}

9. Based on the benefit shown and from your own clinical experience, in which children undergoing heart transplantation do you recommend immunoprophylaxis against serious disease due to RSV infection?

10. Based on the benefit shown and from your own clinical experience, for which children with CHD associated risk factors do you recommend immunoprophylaxis against serious disease due to RSV infection?

11. Based on the benefit shown and from your own clinical experience, for which CHD children do you recommend immunoprophylaxis against serious disease due to RSV infection for the prevention of nosocomial RSV infection if the patient was not previously covered?

12. What are the barriers to effective immunoprophylaxis against serious disease due to RSV infection in children with $\mathrm{CHD}$, including the delivery of that immunoprophylaxis?

13. What management strategies could be put in place to overcome these barriers to effective immunoprophylaxis against serious disease due to RSV infection in children with CHD?

14. In which children with $\mathrm{CHD}$ older than 2 years of age should you consider immunoprophylaxis against serious disease due to RSV infection?

\author{
Recommendation
}

Although children with recurrent

arrhythmias and channelopathies are not

candidates for immunoprophylaxis against

serious disease due to RSV infection per se, it

is recommended that children under 2 years

of age with evidence of hsCHD,

cardiomyopathies, or other forms of CHD,

which current guidelines identify as reasons to implement prophylaxis, should receive immunoprophylaxis during the RSV season Immunoprophylaxis against serious disease due to RSV infection should be considered for children younger than 2 years of age who are on the heart transplant waiting list or children younger than 2 years in their 1 st year after heart transplant

Children under 2 years with a genetic condition or associated condition who have hsCHD, regardless of the primary diagnosis, should receive immunoprophylaxis against serious disease due to RSV infection

Immunoprophylaxis against serious disease due to RSV infection is recommended to prevent the spread of RSV infection during a nosocomial RSV outbreak in all CHD patients younger than 12 months of age who are hospitalised for surgery, interventions, or other medical reasons in a general paediatric area or specific paediatric cardiology area; or hospitalised in a mixed paediatric or neonatal ICU or a cardiac ICU in the perioperative period

A number of barriers have been identified to effective immunoprophylaxis against serious disease due to RSV infection in children with CHD, including poor awareness of RSV disease risks and burden, compliance and completion barriers, data and experience gaps, medical justification and costeffectiveness, and changing RSV seasonality (in tropical and subtropical countries), which makes it difficult to establish an annual immunoprophylaxis schedule

There are a number of recommendations for strategies to help overcome barriers to effective immunoprophylaxis against serious disease due to RSV infection. These include improving awareness of RSV at all levels from the public to healthcare providers There is no recommendation for children with CHD who are older than 2 years, because more information is needed. It is essential to continually update recommendations regarding immunoprophylaxis against serious disease due to RSV virus infection, taking into account both the latest evidence and the professional judgement of expert cardiac care providers to reduce variations and inequity in clinical practice
Voting results (agree/disagree)

$7-1$
Level of evidence

$3 ; 4^{12,1}$

$4^{12,13,15-19,29,37-40}$

$7-1$

$3^{41-44}$

$7-1$

$2 \mathrm{a}^{15,18,42,43,45-48}$

$6-2$

$3 ; 4^{5,18,47,49-52}$ 
The faculty advised (7-1) that the following groups of children younger than 2 years with unoperated CHD are candidates for respiratory syncytial virus immunoprophylaxis: children with haemodynamically significant CHD, as previously defined ${ }^{9}$, including those with acyanotic CHD - left-to-right shunt - requiring therapy, pulmonary hypertension, single-ventricle physiology, and cyanotic CHD, defined by the faculty as oxygen saturations $<85 \%$ on room air, based on clinical experience; and children with CHD who have symptomatic airway abnormalities associated with vascular rings, absent pulmonary valve syndrome, evidence of airway obstruction due to cardiovascular causes, and congenital tracheal stenosis.

\footnotetext{
Question 5: Based on the benefit shown and from your own clinical experience, for which group of children with operated CHD do you recommend immunoprophylaxis against serious disease due to respiratory syncytial virus infection?

Recommendation: Immunoprophylaxis against serious disease due to respiratory syncytial virus infection is recommended for the 1st year of life in children with surgically operated, haemodynamically significant CHD with residual defects or for children aged 1-2 years up to 6 months postoperatively or on a case-by-case basis. Administration of a palivizumab dose immediately after operations involving cardiopulmonary bypass should be considered because of observed decreases in serum palivizumab levels to non-protective levels.

Voting Results: agree/disagree 8-0; Evidence Grade/Level: 1a; $1 b^{9,18,19}$
}

The faculty recommended (8-0) respiratory syncytial virus immunoprophylaxis for the 1 st year of life in children who underwent surgical intervention for CHD but have residual haemodynamically significant problems. Administration of a palivizumab dose after cardiopulmonary bypass surgeries was also recommended because of observed decreases in palivizumab serum concentration levels after this procedure.? Beyond this overarching recommendation, some geographical variations were evident and are described in detail below. On the basis of these variations, it was recommended that in children aged 1-2 years respiratory syncytial virus immunoprophylaxis may also be considered up to 6 months postoperatively, or on an individualised basis.

\section{Geographic variations in recommendations for operated haemodynamically significant CHD}

Some of the expert faculty noted that they would use respiratory syncytial virus immunoprophylaxis in the following groups:

- Children with haemodynamically significant CHD after surgery
- The expert from Germany continues treatment for 6 months - even upon resolution of the haemodynamic defect - to allow time to recover

- Children with palliated CHD

- The expert from Germany continues treatment for 6 months after palliative surgery and preferably during the first 2 years of life

- Children with operated CHD with significant residual defects or airway abnormalities

- One expert from Spain provides immunoprophylaxis up to 1 year, preferably until 2 years, and suggests that there may be additional considerations for certain patients who have had definitive correction of some defects - for example, a patient with Shone syndrome who has had a successful coarctation repair, but has mitral and aortic pathologies, or a patient with tetralogy of Fallot who develops a new pulmonary regurgitation following a successful transannular patch repair - or patients under 1 year of age undergoing certain palliative procedures for example, Blalock-Taussig shunt, pulmonary artery banding, unifocalisation of major aortopulmonary collateral arteries, and staged univentricular pathway repair such as NorwoodGlenn-Fontan procedure.

- The expert from Korea provides respiratory syncytial virus immunoprophylaxis for patients younger than 2 years or with a body weight $<12 \mathrm{~kg}$.

- The expert from Japan provides respiratory syncytial virus immunoprophylaxis for patients younger than 2 years.

- Children with haemodynamically significant CHD in whom surgery is planned during the respiratory syncytial virus season, ending administration of palivizumab at the end of the respiratory syncytial virus season.

\section{Additional recommendations for children with operated haemodynamically significant CHD}

The expert from Mexico recommends respiratory syncytial virus immunoprophylaxis for all the at-risk groups listed above, and additionally considers respiratory syncytial virus immunoprophylaxis for children with heart disease who are scheduled for a diagnostic procedure such as catheterisation during the respiratory syncytial virus season, or who are at risk during the first 2 years of life. The expert from the United Arab Emirates uses clinical judgement on a case-by-case basis in patients with haemodynamically significant CHD with partially corrected CHD, recommending respiratory syncytial virus immunoprophylaxis for the remainder of the respiratory syncytial virus season, or for 2 months, whichever is longest, 
to allow maximum recovery from surgery. Similarly, one expert from the United States of America uses respiratory syncytial virus immunoprophylaxis in children younger than 2 years, at the beginning of the respiratory syncytial virus season, with residual lesions - for example, surgically palliated for augmentation of pulmonary blood flow, palliated with single-ventricle physiology, and systolic or diastolic heart failure requiring congestive heart failure therapy.

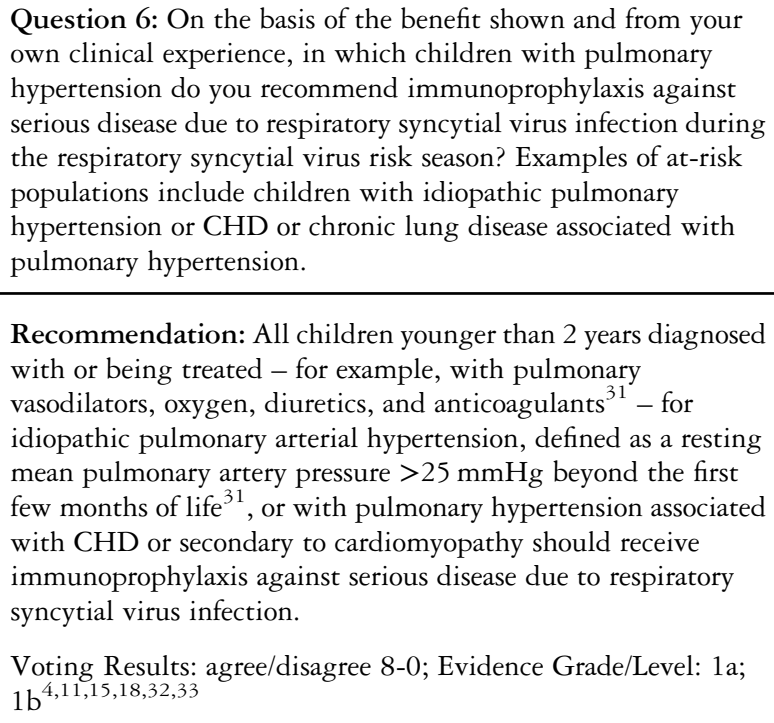

Recommendation: All children younger than 2 years diagnosed with or being treated - for example, with pulmonary vasodilators, oxygen, diuretics, and anticoagulants ${ }^{31}-$ for idiopathic pulmonary arterial hypertension, defined as a resting mean pulmonary artery pressure $>25 \mathrm{mmHg}$ beyond the first few months of life ${ }^{31}$, or with pulmonary hypertension associated with $\mathrm{CHD}$ or secondary to cardiomyopathy should receive immunoprophylaxis against serious disease due to respiratory syncytial virus infection.

Voting Results: agree/disagree 8-0; Evidence Grade/Level: 1a; $1 b^{4,11,15,18,32,33}$

Similar to current guidance regarding prevention of serious disease due to respiratory syncytial virus infection, the faculty agreed (8-0) that all children younger than 2 years diagnosed with or being treated - for example, with pulmonary vasodilators or oxygen, diuretics and anticoagulants ${ }^{31}-$ for idiopathic pulmonary arterial hypertension, defined as a resting mean pulmonary artery pressure $>25 \mathrm{mmHg}$ beyond the first few months of life, ${ }^{31}$ receive respiratory syncytial virus immunoprophylaxis, with or without haemodynamically significant CHD. Screening for pulmonary hypertension in infants may be accomplished by echocardiography, the standard practice, in many cases. A peak tricuspid regurgitant jet velocity $>2.8 \mathrm{~m} / \mathrm{s}$ in the absence of obvious causes for example, right ventricular outflow obstruction, significant residual shunt, or pulmonary venous hypertension - would suggest increased pulmonary vascular resistance or pulmonary arterial hypertension. ${ }^{66}$ Although cardiac catheterisation would not be advisable for all infants in the ICU with suspected pulmonary hypertension, it would be appropriate if a need to start advanced pulmonary vasodilator therapy is indicated in a child with evidence of pulmonary vascular disease. In addition, respiratory syncytial virus immunoprophylaxis is recommended in patients with pulmonary hypertension associated with CHD or secondary to cardiomyopathy. Evidence for respiratory syncytial virus immunoprophylaxis is generally lacking for children, with or without haemodynamically significant $\mathrm{CHD}$, with pulmonary hypertension associated with chronic lung disease due to prematurity or children with neuromuscular disorders. Respiratory syncytial virus immunoprophylaxis, however, is advised for children continuing to receive oxygen therapy.

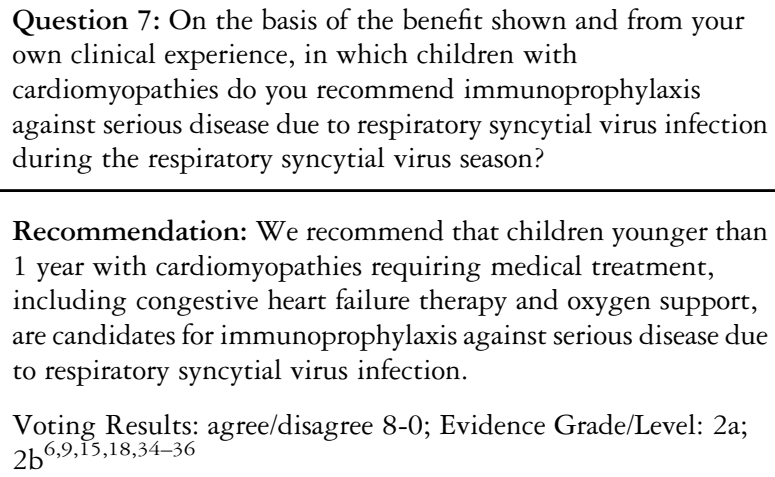

Recommendation: We recommend that children younger than 1 year with cardiomyopathies requiring medical treatment, including congestive heart failure therapy and oxygen support, are candidates for immunoprophylaxis against serious disease due to respiratory syncytial virus infection.

Voting Results: agree/disagree 8-0; Evidence Grade/Level: 2a; $2 b^{6,9,15,18,34-36}$

The faculty noted that currently there are no formal published recommendations for respiratory syncytial virus immunoprophylaxis in infants with cardiomyopathies, even though some evidence exists for the potential benefit in symptomatic children. Despite this lack of formal guidance, the faculty agreed (8-0) on the specific patient populations that may benefit from respiratory syncytial virus immunoprophylaxis during the respiratory syncytial virus season - that is, children younger than 1 year of age with cardiomyopathies requiring medical treatment, such as congestive heart failure therapy and oxygen support - although there were some regional variations in the recommended approaches.

\section{Geographic variation in recommendations for cardiomyopathy}

Experts from Korea, Taiwan, and the United States of America provide respiratory syncytial virus immunoprophylaxis for infants younger than 1 year with haemodynamically significant cardiomyopathy - that is, diuretic dependent, inotrope dependent, or oxygen dependent - consistent with the American Academy of Pediatrics guidance for infants of this age with CHD. ${ }^{18}$ The expert from Japan provides respiratory syncytial virus immunoprophylaxis for children who have haemodynamically significant cardiomyopathy and are 2 years or younger at the beginning of the respiratory syncytial virus season. Experts from Germany and Mexico consider respiratory syncytial virus immunoprophylaxis for infants 
with cardiomyopathies requiring medical treatment. The expert from Mexico also considers respiratory syncytial virus immunoprophylaxis for hospitalised infants with decompensated cardiomyopathy. An expert from the United States of America does not consider respiratory syncytial virus immunoprophylaxis for cases of mild cardiomyopathy in asymptomatic infants not requiring anticongestive therapy; ${ }^{36}$ however, the expert from Mexico considers respiratory syncytial virus immunoprophylaxis for infants younger than 1 year with mild symptoms that do not require medication. ${ }^{15,35,36}$

The group consensus favours respiratory syncytial virus immunoprophylaxis in infants younger than 1 year with cardiomyopathy, but it is advised to review the need for immunoprophylaxis against serious disease due to respiratory syncytial virus infection based on the individual case.

\footnotetext{
Question 8: Based on the benefit shown and from your own clinical experience, in which children with arrhythmias, including Brugada or long QT syndrome, do you recommend immunoprophylaxis against serious disease due to respiratory syncytial virus infection?
}

Recommendation: Although children with recurrent arrhythmias and channelopathies are not candidates for immunoprophylaxis against serious disease due to respiratory syncytial virus infection per se, it is recommended that children under 2 years of age with evidence of haemodynamically significant CHD, cardiomyopathies, or other forms of $\mathrm{CHD}$, which current guidelines identify as reasons to implement prophylaxis, should receive immunoprophylaxis during the respiratory syncytial virus season.

Voting Results: agree/disagree 7-1; Evidence Grade/Level: 3; $4^{12,13,15-19,29,37-40}$

Although at present there is no evidence-based, published guidance regarding the use of respiratory syncytial virus immunoprophylaxis in children with recurrent arrhythmias or rare channelopathies, such as Brugada syndrome and long QT syndrome, the faculty agreed in part on the basis of clinical experience (7-1) that children under 2 years with evidence of haemodynamically significant $\mathrm{CHD}$, cardiomyopathies, or other forms of $\mathrm{CHD}$, which current guidelines identify as reasons to implement respiratory syncytial virus immunoprophylaxis, should receive immunoprophylaxis during the respiratory syncytial virus season. In addition, the faculty noted that children with these conditions need to be protected from fever using standard treatments - that is, paracetamol such as acetaminophen - because febrile illness is an important precipitating factor for paediatric arrhythmias. The faculty also expressed the opinion that further research and studies are needed in this area.
Question 9: Based on the benefit shown and from your own clinical experience, in which children undergoing heart transplantation do you recommend immunoprophylaxis against serious disease due to respiratory syncytial virus infection?

Recommendation: Immunoprophylaxis against serious disease due to respiratory syncytial virus infection should be considered for children younger than 2 years who are on the heart transplant waiting list or children younger than 2 years in their 1st year after heart transplant.

Voting Results: agree/disagree 7-1; Evidence Grade/Level: $3^{41-44}$

There are limited data available for clinical decision making regarding the need for respiratory syncytial virus immunoprophylaxis in children requiring heart transplantation. ${ }^{41-44}$ Evidence exists for increased risks of serious disease due to respiratory syncytial virus infection in immunocompromised patients, due to congenital/acquired immunodeficiency, haematological malignancy, haematopoietic stem cell or solid organ transplants, and use of immunosuppressive agents, ${ }^{42}$ and some guidelines contain recommendations regarding use of immunoprophylaxis in patients with severe immunodeficiencies ${ }^{10,18}$ or receiving a heart transplant. ${ }^{14,15,18}$ Similarly, there are a few published data on the importance of checking for the presence of respiratory syncytial virus in hearts from potential donors. Nonetheless, the faculty agreed (7-1) that respiratory syncytial virus immunoprophylaxis needs to be considered in children younger than 2 years who are on the heart transplant waiting list. Furthermore, respiratory syncytial virus immunoprophylaxis, at standard doses according to the product label, is recommended for children younger than 2 years in their 1st year after heart transplantation because of the immunocompromised condition of these patients.

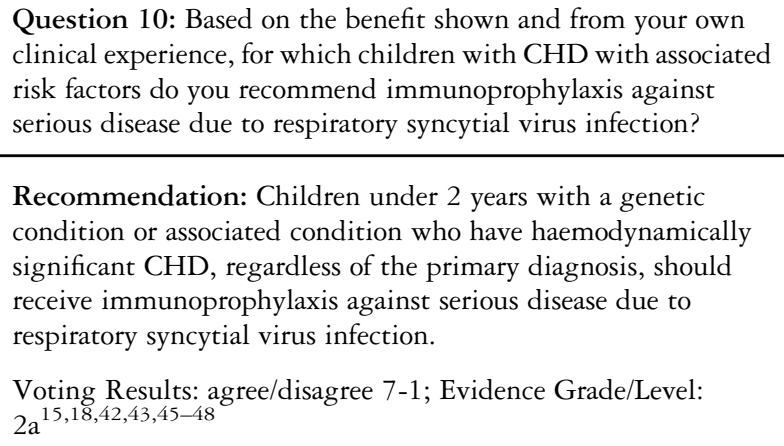

Recommendation: Children under 2 years with a genetic condition or associated condition who have haemodynamically significant CHD, regardless of the primary diagnosis, should receive immunoprophylaxis against serious disease due to respiratory syncytial virus infection.

Voting Results: agree/disagree 7-1; Evidence Grade/Level: $2 \mathrm{a}^{15,18,42,43,45-48}$

A number of genetic conditions such as Down syndrome or chromosome 22q11 microdeletion may be associated with CHD. In addition, many infants and children with primary or acquired immunodeficiency may be at increased risk of CHD. The faculty agreed in part on the basis of clinical experience (7-1) 
that children aged $<2$ years with these conditions should receive respiratory syncytial virus immunoprophylaxis if haemodynamically significant CHD is present, regardless of the primary diagnosis. Routine respiratory syncytial virus immunoprophylaxis was not recommended for children with other conditions that may involve $\mathrm{CHD}$ if there was no haemodynamic impact - for example, secundum atrial septal defect/small ventricular septal defect, pulmonary stenosis, aortic stenosis, mild coarctation, patent ductus arteriosus, and restrictive interventricular shunting.

\section{Geographic variation in recommendations for associated risk factors}

The experts from Colombia and Spain consider respiratory syncytial virus immunoprophylaxis in all children with Down syndrome younger than 2 years with unoperated, non-significant CHD or nonsignificant residual postoperative defects - that is, mild mitral regurgitation - or airway abnormalities.

In a study conducted in Spain, CIVIC 21, ${ }^{67}$ children with Down syndrome with non-haemodynamically significant $\mathrm{CHD}$ had a higher hospital admission rate for respiratory infection - that is, with any and related to respiratory syncytial virus infection - than children with Down syndrome with haemodynamically significant $\mathrm{CHD}$. These findings suggest that patients with Down syndrome and coexistent haemodynamically significant CHD may be more likely to receive palivizumab prophylaxis, and thus are protected against serious disease due to respiratory syncytial virus infection.

The expert from Japan recommends respiratory syncytial virus immunoprophylaxis with palivizumab in children with CHD, including those with no significant signs/symptoms or with complete repair, who are 24 months of age or younger at the beginning of the respiratory syncytial virus season with either chromosomal or genetic abnormalities - for example, Down syndrome, Trisomy 21, other trisomy, or 22q11.2 deletion syndrome - or other types of congenital anomalies with functional/organic respiratory system abnormalities.

Question 11: Based on the benefit shown and from your own clinical experience, for which CHD children do you recommend immunoprophylaxis against serious disease due to respiratory syncytial virus infection for the prevention of nosocomial respiratory syncytial virus infection if the patient was not previously covered?

Recommendation: Immunoprophylaxis against serious disease due to respiratory syncytial virus infection is recommended to prevent the spread of respiratory syncytial virus infection during a nosocomial respiratory syncytial virus outbreak in all CHD patients younger than 12 months of age who are hospitalised for surgery, interventions, or other medical reasons in a general paediatric area or specific paediatric cardiology area; or hospitalised in a mixed paediatric/neonatal ICU or cardiac ICU in the perioperative period.

Voting Results: agree/disagree 6-2; Evidence Grade/Level: 3; $4^{5,18,47,49-52}$

During a nosocomial outbreak, it was recommended (6-2) that respiratory syncytial virus immunoprophylaxis be used in patients with CHD younger than 1 year who are hospitalised for surgery, diagnostic intervention or palliative procedure interventions, or other medical reasons including injury or infection in either a general paediatric or a specific paediatric cardiology area, as well as those hospitalised in either a mixed paediatric/neonatal ICU or a cardiac ICU in the perioperative period. Some clinicians recommend respiratory syncytial virus immunoprophylaxis for all children with CHD who are younger than 1 year if they are admitted as inpatients, whereas others only recommend respiratory syncytial virus immunoprophylaxis for those children undergoing cardiac surgery during respiratory syncytial virus season.

The faculty considers offering respiratory syncytial virus immunoprophylaxis during a nosocomial respiratory syncytial virus outbreak to the following groups of children with CHD between 1 and 2 years, if not previously covered:

- Infants meeting criteria for chronic lung disease of prematurity and continuing to need medical aid for the condition

- Children with cyanotic or non-cyanotic CHD, noncorrected or partially corrected

- Children with complex heart diseases, palliative intervention, who have haemodynamic sequelae such as moderate-to-severe pulmonary hypertension, heart failure, or hypoxaemia

- Children with surgically corrected CHD with residual lesions with haemodynamic sequelae

- Children with surgically corrected CHD and a history of severe lung complications, requiring prolonged mechanical ventilation

- Children with immediate postoperative haemodynamic sequelae

- Children undergoing treatment for cardiomyopathy

- Children with heart disease with a planned therapeutic diagnostic procedure - for example, catheterisation

Question 12: What are the barriers to effective immunoprophylaxis against serious disease due to respiratory syncytial virus infection in children with CHD, including the delivery of that immunoprophylaxis?

Recommendation: A number of barriers have been identified to effective immunoprophylaxis against serious disease due to 
respiratory syncytial virus infection in children with CHD, including poor awareness of respiratory syncytial virus disease risks and burden, compliance and completion barriers, data and experience gaps, medical justification and costeffectiveness, and changing respiratory syncytial virus seasonality, in tropical and subtropical countries, which makes it difficult to establish an annual immunoprophylaxis schedule.

Voting Results: agree/disagree 7-1; Evidence Grade/Level: $4^{15,18,21,24,25,50,53-61}$

On the basis of clinical experience and a review of the literature, the faculty identified (7-1) a number of barriers to effective respiratory syncytial virus immunoprophylaxis in children with CHD - for example, poor awareness of respiratory syncytial virus infection and disease risks and the burden of disease $\mathrm{e}^{5,56,60}$ were cited and attributed to several factors, including variable definitions of at-risk children, lack of agreement and clarity on a multidisciplinary approach to respiratory syncytial virus immunoprophylaxis, and limited awareness of the impact of respiratory syncytial virus infection among healthcare providers who started their careers after immunoprophylaxis became available. Other respiratory syncytial virus immunoprophylaxis barriers identified included fear of injections, concerns about potential adverse effects related to therapy, and failure, by both healthcare providers and parents, to understand the importance of respiratory syncytial virus immunoprophylaxis regimen completion - that is, administration of all prescribed doses. ${ }^{21,57-59}$ Knowledge gaps, both data and experience, were cited as another barrier, especially because there is paucity of clinical evidence available - clinical trial and observational data - to support use of respiratory syncytial virus immunoprophylaxis in certain cases. In addition, issues with medical justification and cost-effectiveness exist because of limited awareness of available evidence-based data regarding costeffectiveness. $^{24,25}$

\section{Geographical variation in barriers to respiratory syncytial virus immunoprophylaxis}

Patterns of respiratory syncytial virus seasonality are related to multiple factors including climate for example, diurnal and seasonal temperature excursions, humidity, latitude, and ultraviolet $\mathrm{B}$ radiation. ${ }^{68-70}$ In tropical and subtropical countries, variability in the rainy season makes defining the onset of respiratory syncytial virus season challenging. Consequently, an appropriate and effective annual respiratory syncytial virus immunoprophylaxis schedule is difficult to establish. ${ }^{61}$
Question 13: What management strategies could be put in place to overcome these barriers to effective immunoprophylaxis against serious disease due to respiratory syncytial virus infection in children with $\mathrm{CHD}$ ?

Recommendation: There are a number of recommendations for strategies to help overcome barriers to effective

immunoprophylaxis against serious disease due to respiratory syncytial virus infection. These include improving awareness of respiratory syncytial virus at all levels from the public to healthcare providers.

Voting Results: agree/disagree 8-0; Evidence Grade/Level: 1a; $4^{15,21,53,57-59,62}$

The faculty agreed (8-0) that there are multiple strategies to remove barriers of effective respiratory syncytial virus immunoprophylaxis, including improving awareness of respiratory syncytial virus at all levels. Educational efforts conducted by relevant stakeholders - for example, paediatric cardiologists, paediatricians, other healthcare providers, professional medical societies, and health authorities regarding respiratory syncytial virus infection should extend from increased awareness among the public to improved communication of risk-prevention measures to all healthcare professionals who care for key at-risk groups of children.

To support improved awareness of the clinical impact of respiratory syncytial virus, including the importance of respiratory syncytial virus immunoprophylaxis in children with CHD, establishment of local, regional, national, and international registries was considered useful for capturing more observational data and experiences in at-risk children. This data capture method not only provides continuous reporting of respiratory syncytial virus epidemiology in children with CHD and the potential effectiveness of prophylaxis, but also could serve as a valuable source of data to support outbreak-containment efforts. Suggested strategies include web-based databases, preferably centralised, use of an online data collection form, analyses, and educational activities such as lectures for healthcare providers involved in the care of patient populations of interest. As an example, cases of respiratory syncytial virus infection in the United Arab Emirates can be entered into an online registry website that serves as a source of continuous surveillance, data collection, and advice.

Question 14: In which children with CHD older than 2 years should you consider immunoprophylaxis against serious disease due to respiratory syncytial virus infection?

Recommendation: There is no recommendation for children with $\mathrm{CHD}$ who are older than 2 years, because more information is needed. It is essential to continually update recommendations regarding immunoprophylaxis against serious disease due to 
respiratory syncytial virus infection, taking into account both the latest evidence and the professional judgement of expert cardiac care providers to reduce variations and inequity in clinical practice.

Voting Results: agree/disagree 8-0; Evidence Grade/Level: 3; $4^{5,9,60,63-65}$

There is no recommendation for children with CHD older than 2 years, because more information is needed. The faculty agreed (8-0) that there is a continual need to update respiratory syncytial virus immunoprophylaxis recommendations based on new evidence and the evolving clinical expertise of cardiac care providers striving for consistency in clinical practice care standards. More evidence and greater clinical experience are required to provide more comprehensive recommendations on the management of risk in patient groups not currently described in formal guidelines or addressed in these recommendations - for example patients older than 2 years with serious $\mathrm{CHD}$, older children awaiting heart transplants, patients with haematological cancers, immunocompromised patients, patients with Down syndrome or 22q11.2 deletion syndrome, and older children with chronic lung disease, pulmonary hypertension, and haemodynamically significant CHD, and elderly patients with serious CHD. Furthermore, increased use of registries to capture data regarding respiratory syncytial virus and respiratory syncytial virus immunoprophylaxis would help inform future clinical practice.

\section{Discussion}

These recommendations regarding immunoprophylaxis against serious disease due to respiratory syncytial virus infection reflect the agreement of an international group of clinicians with expertise in the care of children with CHD. There was a clear agreement and the most robust clinical evidence for respiratory syncytial virus immunoprophylaxis in children younger than 2 years with either unoperated haemodynamically significant CHD - including acyanotic CHD requiring therapy, single-ventricle physiology, or with cyanosis (oxygen saturation $<85 \%$ ) - or pulmonary hypertension - idiopathic, associated with $\mathrm{CHD}$, or secondary to cardiomyopathy - or children younger than 1 year who had surgical intervention for haemodynamically significant CHD (Questions 4-6; Level 1a evidence for all). The recommendations for these conditions are somewhat different from many guidelines (Table 1), especially in terms of suggested age - that is, children aged $<2$ years versus $<1$ year - but are most consistent with those in guidance documents for Japan ${ }^{13}$ and Mexico/Spain. ${ }^{15}$
For children between 1 and 2 years with early surgical intervention for $\mathrm{CHD}$, respiratory syncytial virus immunoprophylaxis was also recommended for up to 6 months postoperatively or on a case-by-case basis; however, there was some difference in opinion about the duration of immunoprophylaxis continuation in the postsurgical period. Individualised case decisions may be required and depend on the intention and outcome of the surgical invention - that is, if the surgery is palliative, there may be general agreement for prophylaxis for at least the duration of the respiratory syncytial virus season. In cases of complete surgical correction, immunoprophylaxis decisions may seem less clear; however, for all children with operated CHD - that is, both palliative and fully corrective continuation of prophylaxis may be appropriate to allow ample time for overall recovery and physiological remodelling. In addition, because a $>50 \%$ decrease in palivizumab serum concentration levels - that is, to non-protective levels - has been demonstrated after cardiopulmonary bypass, administration of a palivizumab dose after surgeries of this type should be considered to fully protect patients against the risk of severe disease due to respiratory syncytial virus infection during the vulnerable recovery period. ${ }^{9}$

There is limited information in the literature regarding the relationship between respiratory syncytial virus infection and acute pulmonary hypertension associated with surgery. Khongphatthanayothin et $\mathrm{al}^{52}$ found that infants who underwent cardiopulmonary bypass during a hospital admission with acute respiratory syncytial virus infection had a higher risk of complications. These data support the practice of delaying cardiac surgery until at least 6 weeks after the initial diagnosis of respiratory syncytial virus infection. Although there was no direct evidence for pulmonary hypertension in this study, ICU-admitted infants may have pulmonary vascular reactivity with extreme alterations in their oxygen saturation levels, resulting in a complicated clinical management scenario. A potential mechanism for pulmonary hypertension occurrence was described by Carpenter and Stenmark, who cited demonstration of a profound cuff of inflammatory cells around the pulmonary capillaries in a primate model of respiratory syncytial virus infection; this pathology could lead to hypoxia and hypercapnia by making gas exchange more difficult. ${ }^{71}$ However, although hypoxaemia may occur in children in the perioperative period after respiratory syncytial virus infection, there was no evidence of chronic pulmonary hypertension in findings reported from a large, randomised, clinical trial of children with CHD $(n=1287)^{72}$ or in our own clinical experience.

The panel also agreed that respiratory syncytial virus immunoprophylaxis was recommended for children younger than 2 years either on heart transplant waiting 
lists or in their 1st year after heart transplant (Question 9) and children younger than 1 year with cardiomyopathies requiring treatment (Question 7), but existing evidence for these conditions was somewhat less robust, and the clinical experience of the expert group was used to supplement gaps in the clinical evidence for recommendation formulation, although any available evidence was considered. The recommendation regarding transplantation (Level 3 evidence) is more definitive but consistent with some existing guidance documents (Table 1) regarding use of immunoprophylaxis in patients with severe immunodeficiencies ${ }^{10,18}$ or receiving a heart transplant. ${ }^{14,15,18}$ The expert group also recommended respiratory syncytial virus immunoprophylaxis in children younger than 1 year with cardiomyopathies who required medical treatment including congestive heart failure therapy or oxygen support (Level 2a; 2b evidence). This recommendation is similar to that contained in guidance documents from the United Kingdom. ${ }^{17}$ Japanese guidelines ${ }^{13}$ suggest respiratory syncytial virus immunoprophylaxis in children with haemodynamically significant cardiomyopathy younger than 2 years at the start of the respiratory syncytial virus season. Respiratory syncytial virus immunoprophylaxis was also recommended for children with recurrent arrhythmias and channelopathies (Question 8) if these conditions coexist with haemodynamically significant $\mathrm{CHD}$, cardiomyopathies, or other forms of CHD, according to international and/or country-specific guidelines for the latter co-morbidities (Level 3, 4 evidence). Children with Down syndrome have an increased susceptibility to infections due to multiple factors including innate immune system abnormalities such as reduced thymus size, lymphocyte counts, and antibody response; anatomical, physiological or functional abnormalities such as poor airway muscle tone, abnormal lung development, and respiratory response; and presence of co-morbidities such as CHD and chronic ear infections. ${ }^{73}$ On the basis of available data, the faculty recommended immunoprophylaxis against serious disease due to respiratory syncytial virus infection for children with a genetic or associated condition if haemodynamically significant $\mathrm{CHD}$ was present, regardless of the primary diagnosis (Question 10, Level 2a evidence). In comparison, Japanese guidelines ${ }^{13}$ recommend immunoprophylaxis in all children with CHD and chromosomal/genetic abnormalities - for example Trisomy 21/Down syndrome, other trisomy, or 22q11.2 deletion syndrome younger than 24 months at the start of respiratory syncytial virus season, even if there are no significant signs/symptoms or a complete resolution of CHD. The updated American Academy of Pediatrics guidance ${ }^{18}$ only recommends routine use of palivizumab in children with Down syndrome if there is coexisting haemodynamically significant $\mathrm{CHD}$, chronic lung disease, airway clearance issues, or prematurity - that is, $<29$ weeks, 0 days of gestation.

Opinion was divided for the use of respiratory syncytial virus immunoprophylaxis in children older than 1 year, in nosocomial outbreaks, in children with immune deficiencies, and in those being admitted for cardiac interventions such as corrective surgery, palliative procedures, or diagnostic intervention, which is not unexpected because these areas have limited, less robust clinical evidence or are not well addressed in international guidelines. The expert group recommended respiratory syncytial virus immunoprophylaxis to prevent the spread of respiratory syncytial virus infection during a nosocomial respiratory syncytial virus outbreak in select groups of hospitalised patients younger than 1 year with CHD (Question 12; Level 3, 4 evidence). In contrast, the American Academy of Pediatrics guidance ${ }^{18}$ does not recommend respiratory syncytial virus immunoprophylaxis to control outbreaks of healthcare-associated disease. In many of these clinical scenarios, treatment decisions will need to be made on the basis of the individual case - for example, if a child is admitted for a relatively simple cardiac intervention procedure, there may be no need for respiratory syncytial virus immunoprophylaxis; however, if major cardiac surgery is planned during an outbreak of respiratory syncytial virus, prophylaxis could be considered. In addition, individual healthcare providers must frequently make immunoprophylaxis decisions for patients who have previously experienced severe disease due to respiratory syncytial virus infection; it is suggested that continuation of immunoprophylaxis would be appropriate in these circumstances because recent infection does not confer immunity.

For children older than 2 years, the group determined that more data are needed (Question 14; Level 3, 4 evidence). It should be noted that a full understanding of the risks of severe disease due to respiratory syncytial virus infection in the 2 nd year of life continues to evolve. Recent studies have found that children between 12 and 23 months with certain CHD diagnoses have significantly increased risk of hospitalisation due to respiratory syncytial virus infection compared with children without $\mathrm{CHD},{ }^{74}$ and that children younger than 2 years with congenital airway anomalies, without CHD, who received immunoprophylaxis during 1 or 2 respiratory syncytial virus seasons had the same likelihood of respiratory syncytial virus-related hospitalisation in the two virus seasons. ${ }^{75}$

Finally, there was general consensus that respiratory syncytial virus immunoprophylaxis needs to be more available in countries with limited resources for example, economic/budget constraints or limited cross-functional support. It was also recognised that there is insufficient evidence to guide its use in 
subtropical and tropical countries and in patients with certain co-morbidities.

Risks associated with lower respiratory tract infections are a concern in children with CHD; these types of infections may have a complex aetiology, and the full spectrum of potential causes - for example, other viral and bacterial pathogens - and available preventive measures - for example, active vaccination to prevent pneumonia - must be considered in care decisions for these patients. ${ }^{76}$ At present, there is no approved vaccine for respiratory syncytial virus infection, which is an area for further study. Future research is also warranted for increased understanding of respiratory syncytial virus infection and effective immunoprophylaxis guidance, including the effect of seasonality - for example, in areas with lack of seasons or with two seasons a year - effect of co-morbid conditions - for example, Down syndrome, neuromuscular disease, airway diseases, or immunodeficiency - and age considerations - for example, use in children aged 2-3 years or the elderly and identification of optimal age for immunoprophylaxis implementation. Additional information in these and other areas could guide more effective disease prevention strategies and more conclusive, universal prophylaxis recommendations.

The key strength of these recommendations is that they were devised using a practical and efficient consensus-building methodology with input from a diverse, international group of paediatric heart disease experts, although it should be noted that the full Delphi method was not used. The primary limitation of these recommendations is the paucity of robust clinical evidence in certain patient subgroups and clinical situations. In addition, the reported regional variations are of interest, but may not fully reflect geographic differences because the opinions of this geographically diverse group of experts may not be representative of other clinicians from the respective regions. In conclusion, these recommendations provide needed guidance to healthcare providers who care for children at high risk of serious disease due to respiratory syncytial virus infection, including some vulnerable clinical populations that are not sufficiently addressed in current evidence-based guidelines.

\section{Acknowledgements}

None.

\section{Financial Support}

Financial support for this steering committee was provided by AbbVie Inc. Medical writing support was provided by John E. Fincke, PhD, Lisa M.
Havran, $\mathrm{PhD}$, and Kulvinder Katie Singh, PharmD, at Complete Publication Solutions, LLC (North Wales, PA); this support was funded by AbbVie.

\section{Conflicts of Interest}

R.M.R.T. and C.M.-L. have received lecture and consultancy fees from AbbVie. P.A.C. and C.S. have served as consultants for AbbVie; P.A.C. has also received research support from AstraZeneca. N.S. has received lecture fees from AbbVie. J.M.G.-J. has received fees from AbbVie. M.G., E.J.B., A.J., M.-H.W., T.F., A.D.-K., and R.T. have all served as consultants for AbbVie during the execution of this study. G.N. and C.W. are employees of AbbVie and may own stock or stock options. As some of the authors are employees of AbbVie, the role of the sponsor (AbbVie) included contributions to the writing, review, and approval of this manuscript: AbbVie participation at the steering committee meeting was limited to observing and providing product/ scientific information on request.

\section{References}

1. American Academy of Pediatrics. Respiratory syncytial virus. In: Pickering LK, Baker CJ, Kimberlin DW, Long SS (eds). Red Book: 2012 Report of the Committee on Infectious Diseases. American Academy of Pediatrics, Elk Grove Village, 2012: 609-617.

2. Lozano R, Naghavi M, Foreman K, et al. Global and regional mortality from 235 causes of death for 20 age groups in 1990 and 2010: a systematic analysis for the Global Burden of Disease Study 2010. Lancet 2012; 380: 2095-2128.

3. Hall CB, Weinberg GA, Blumkin AK, et al. Respiratory syncytial virus-associated hospitalizations among children less than 24 months of age. Pediatrics 2013; 132: e341-e348.

4. MacDonald NE, Hall CB, Suffin SC, Alexson C, Harris PJ, Manning JA. Respiratory syncytial viral infection in infants with congenital heart disease. N Engl J Med 1982; 307: 397-400.

5. Geskey JM, Cyran SE. Managing the morbidity associated with respiratory viral infections in children with congenital heart disease. Int J Pediatr 2012; 2012: 646780.

6. Jung JW. Respiratory syncytial virus infection in children with congenital heart disease: global data and interim results of Korean RSV-CHD survey. Korean J Pediatr 2011; 54: 192-196.

7. Cabalka AK. Physiologic risk factors for respiratory viral infections and immunoprophylaxis for respiratory syncytial virus in young children with congenital heart disease. Pediatr Infect Dis J 2004; 23: S41-S45.

8. Boyce TG, Mellen BG, Mitchel EF, Jr., Wright PF, Griffin MR. Rates of hospitalization for respiratory syncytial virus infection among children in medicaid. J Pediatr 2000; 137: 865-870.

9. Feltes TF, Cabalka AK, Meissner HC, et al. Palivizumab prophylaxis reduces hospitalization due to respiratory syncytial virus in young children with hemodynamically significant congenital heart disease. J Pediatr 2003; 143: 532-540.

10. Robinson JL, Le Saux N. Preventing hospitalizations for respiratory syncytial virus infection. Paediatr Child Health 2015; 20: 321-333.

11. Chantepie A, Bureau de la Filiale de Cardiologie Pediatrique de la Societe Francaise de Cardiologie. Use of palivizumab for the prevention of respiratory syncytial virus infections in children with congenital heart disease: recommendations from the French 
Paediatric Cardiac Society [in French]. Arch Pediatr 2004; 11: 1402-1405.

12. Liese J. RSV prophylaxis with palivizumab in high-risk children update German national guidelines 2008. Monatsschr Kinderheilkd 2009; 157: 61-64.

13. Nakazawa M, Saji T, Ichida F, Oyama K, Harada K, Kusuda S Guidelines for the use of palivizumab in infants and young children with congenital heart disease. Pediatr Int 2006; 48: 190-193.

14. Bollani L, Baraldi E, Chirico G, et al. Revised recommendations concerning palivizumab prophylaxis for respiratory syncytial virus (RSV). Ital J Pediatr 2015; 41: 97.

15. Medrano Lopez C, Garcia-Guereta L, Fernandez Pineda L, et al. Clinical consensus on respiratory syncytial virus (RSV) infection prophylaxis and the use of palivizumab in paediatric cardiology [in Spanish]. An Pediatr (Barc) 2010; 72: 432.e1-e13.

16. Society of Neonatology Taiwan and Taiwan Society of Pediatric Cardiology. Recommendations for palivizumab vaccination. In: Recommendations for Prevention of RSV Infection in Taiwan. Society of Neonatology Taiwan and Taiwan Society of Pediatric Cardiology, Taipei, 2015: 19-22.

17. Tulloh R, Marsh M, Blackburn M, et al. Recommendations for the use of palivizumab as prophylaxis against respiratory syncytial virus in infants with congenital cardiac disease. Cardiol Young 2003; 13: $420-423$.

18. American Academy of Pediatrics Committee on Infectious Diseases, American Academy of Pediatrics Bronchiolitis Guidelines Committee. Updated guidance for palivizumab prophylaxis among infants and young children at increased risk of hospitalization for respiratory syncytial virus infection. Pediatrics 2014; 134: 415-420.

19. American Academy of Pediatrics Committee on Infectious Diseases, Committee on Fetus and Newborn. Revised indications for the use of palivizumab and respiratory syncytial virus immune globulin intravenous for the prevention of respiratory syncytial virus infections. Pediatrics 2003; 112: 1442-1446.

20. Hsu CC, Sandford BA. The Delphi technique: making sense of consensus. Pract Assess Res Eval 2007; 12: 1-8.

21. Tulloh RM, Feltes TF. The European Forum for Clinical Management: prophylaxis against the respiratory syncytial virus in infants and young children with congenital cardiac disease. Cardiol Young 2005; 15: 274-278.

22. Andabaka T, Nickerson JW, Rojas-Reyes MX, Rueda JD, Bacic Vrca V, Barsic B. Monoclonal antibody for reducing the risk of respiratory syncytial virus infection in children. Cochrane Database Syst Rev 2013; 4: CD006602.

23. Hussman JM, Lanctot KL, Paes B. The cost effectiveness of palivizumab in congenital heart disease: a review of the current evidence. J Med Econ 2013; 16: 115-124.

24. Wang D, Bayliss S, Meads C. Palivizumab for immunoprophylaxis of respiratory syncytial virus (RSV) bronchiolitis in high-risk infants and young children: a systematic review and additional economic modelling of subgroup analyses. Health Technol Assess 2011; 15: iii-iv; 1-124.

25. Wang D, Cummins C, Bayliss S, Sandercock J, Burls A. Immunoprophylaxis against respiratory syncytial virus (RSV) with palivizumab in children: a systematic review and economic evaluation. Health Technol Assess 2008; 12: iii, ix-x, 1-86.

26. McKenna HP. The Delphi technique: a worthwhile research approach for nursing? J Adv Nurs 1994; 19: 1221-1225.

27. Howick J, Chalmers I, Glasziou P, et al. 'The Oxford Levels of Evidence 2'. Oxford Centre for Evidence-Based Medicine, 2011. Retrieved September 1, 2016, from http://www.cebm.net/index. aspx? $=5653$.

28. Bellavance M, Rohlicek CV, Bigras JL, et al. Palivizumab use among children with congenital heart disease in Quebec: impact of Canadian guidelines on clinical practice. Paediatr Child Health 2006; 11: 19-23.
29. Korean Ministry of Health \& Welfare. Reimbursement guidelines. Data on file, 2012.

30. German Society for Paediatric Infectious Diseases (DGPI), German Society of Pediatric Cardiology (DGPK), Society of Pediatric Pneumology (GPP), Society of Neonatology and Pediatric Intensive Care Medicine (GNPI) and Professional Association of Child and Adolescent Physicians (BVKJ). [Guideline for the prevention of serious illnesses by respiratory syncytial virus in children at risk]. Retrieved June 2, 2016, from http://www.awmf.org/uploads/ tx_szleitlinien/048-0121_S2k_Prophylaxe_von_schweren_RSV Erkrankungen_bei_Risikokindern_07-2012-12-2016.pdf.

31. Abman SH, Hansmann G, Archer SL, et al. Pediatric pulmonary hypertension: guidelines from the American Heart Association and American Thoracic Society. Circulation 2015; 132: 2037-2099.

32. Gaboli M, de la Cruz OA, de Aguero MI, Moreno-Galdo A, Perez GP, de Querol MS. Use of palivizumab in infants and young children with severe respiratory disease: a Delphi study. Pediatr Pulmonol 2014; 49: 490-502.

33. Farquhar M, Fitzgerald DA. Pulmonary hypertension in chronic neonatal lung disease. Paediatr Respir Rev 2010; 11: 149-153.

34. Kristensen K, Stensballe LG, Bjerre J, et al. Risk factors for respiratory syncytial virus hospitalisation in children with heart disease. Arch Dis Child 2009; 94: 785-789.

35. Leslie N, Bailey L. Pompe disease. In: Pagon RA, Adam MP, Ardinger HH, et al (eds). Gene Reviews. Seattle, WA: University of Washington, Seattle; 1993-2017. Retrieved May 25, 2017 from https://www.ncbi.nlm.nih.gov/books/NBK1261/.

36. Alexander PM, Eastaugh L, Royle J, Daley AJ, Shekerdemian LS, Penny DJ. Respiratory syncytial virus immunoprophylaxis in highrisk infants with heart disease. J Paediatr Child Health 2012; 48: 395-401.

37. Donnerstein RL, Berg RA, Shehab Z, Ovadia M. Complex atrial tachycardias and respiratory syncytial virus infections in infants. J Pediatr 1994; 125: 23-28.

38. Fujita S, Nakayama Y, Usuda K, Hanaoka R, Yamada K, Hatasaki $\mathrm{K}$. Catheter ablation for right ventricular outflow tract ventricular tachycardia induced by fever in a 7-year-old girl. Pediatr Cardiol 2010; 31: 128-131.

39. Esposito $\mathrm{S}$, Salice $\mathrm{P}$, Bosis $\mathrm{S}$, et al. Altered cardiac rhythm in infants with bronchiolitis and respiratory syncytial virus infection. BMC Infect Dis 2010; 10: 305.

40. Yamamoto A, Nakamura K, Matsumoto S, et al. VLCAD deficiency in a patient who recovered from ventricular fibrillation, but died suddenly of a respiratory syncytial virus infection. Pediatr Int 2013; 55: 775-778.

41. Grodin JL, Wu KS, Kitchell EE, et al. Respiratory syncytial virus pneumonia treated with lower-dose palivizumab in a heart transplant recipient. Case Rep Cardiol 2012; 2012: 723407.

42. Mori M, Morio T, Ito S, et al. Risks and prevention of severe RS virus infection among children with immunodeficiency and Down's syndrome. J Infect Chemother 2014; 20: 455-459.

43. Chavez-Bueno S, Mejias A, Merryman RA, Ahmad N, Jafri HS, Ramilo O. Intravenous palivizumab and ribavirin combination for respiratory syncytial virus disease in high-risk pediatric patients. Pediatr Infect Dis J 2007; 26: 1089-1093.

44. Michaels MG, Fonseca-Aten M, Green M, et al. Respiratory syncytial virus prophylaxis: a survey of pediatric solid organ transplant centers. Pediatr Transplant 2009; 13: 451-456.

45. Kristensen K, Hjuler T, Ravn H, Simoes EA, Stensballe LG. Chronic diseases, chromosomal abnormalities, and congenital malformations as risk factors for respiratory syncytial virus hospitalization: a populationbased cohort study. Clin Infect Dis 2012; 54: 810-817.

46. Stagliano DR, Nylund CM, Eide MB, Eberly MD. Children with Down syndrome are high-risk for severe respiratory syncytial virus disease. J Pediatr 2015; 166: 703-709.e702.

47. Ashkenazi-Hoffnung L, Dotan M, Livni G, Amir J, Bilavsky E. Nosocomial respiratory syncytial virus infections in the 
palivizumab-prophylaxis era with implications regarding high-risk infants. Am J Infect Control 2014; 42: 991-995.

48. Tsang R, Checchia PA, Bronicki R, Moffett B, Morris SA. Mortality and morbidity of respiratory syncytial virus bronchiolitis in congenital heart disease patients 1999-2012 - a populationbased study. Congenit Heart Dis 2014; 9: 465.

49. Saadah LM, Chedid FD, Sohail MR, Nazzal YM, Al Kaabi MR, Rahmani AY. Palivizumab prophylaxis during nosocomial outbreaks of respiratory syncytial virus in a neonatal intensive care unit: predicting effectiveness with an artificial neural network model. Pharmacotherapy 2014; 34: 251-259.

50. Bergman G, Haerskjold A, Stensballe LG, Kieler H, Linder M. Children with hemodynamically significant congenital heart disease can be identified through population-based registers. Clin Epidemiol 2015; 7: 119-127.

51. Figueras Aloy J, Lopez Sastre J, Medrano Lopez C, et al. Spanish multidisciplinary consensus on the prevention of respiratory syncytial virus infection in children [in Spanish]. An Pediatr (Barc) 2008; 69: 63-71.

52. Khongphatthanayothin A, Wong PC, Samara Y, et al. Impact of respiratory syncytial virus infection on surgery for congenital heart disease: postoperative course and outcome. Crit Care Med 1999; 27: 1974-1981.

53. Hashmi NA, Cosgrove JF, MacMahon P. Prophylaxis in RSV infection (palivizumab) - is it worthwhile? Ir Med J 2000; 93: 284.

54. Granbom E, Fernlund E, Sunnegardh J, Lundell B, Naumburg E. Evaluating national guidelines for the prophylactic treatment of respiratory syncytial virus in children with congenital heart disease. Acta Paediatr 2014; 103: 840-845.

55. Danziger-Isakov LA, Arslan D, Sweet S, Benden C, Goldfarb S, Wong J. RSV prevention and treatment in pediatric lung transplant patients: a survey of current practices among the International Pediatric Lung Transplant Collaborative. Pediatr Transplant 2012; 16: 638-644.

56. Moynihan JA, Kim TY, Young T, Checchia PA. Rate of palivizumab administration in accordance with current recommendations among hospitalized children. J Pediatr Health Care 2004; 18: 224-227.

57. Anderson KS, Mullally VM, Fredrick LM, Campbell AL. Compliance with RSV prophylaxis: global physicians' perspectives. Patient Prefer Adherence 2009; 3: 195-203.

58. Medrano C, Garcia-Guereta L, Grueso J, et al. Respiratory infection in congenital cardiac disease. Hospitalizations in young children in Spain during 2004 and 2005: the CIVIC Epidemiologic Study. Cardiol Young 2007; 17: 360-371.

59. Resch B, Michel-Behnke I. Respiratory syncytial virus infections in infants and children with congenital heart disease: update on the evidence of prevention with palivizumab. Curr Opin Cardiol 2013; 28: 85-91.

60. Robinson JL, Grenier D, MacLusky I, Allen UD. Respiratory syncytial virus infections in pediatric transplant recipients: a Canadian Paediatric Surveillance Program study. Pediatr Transplant 2015; 19: 659-662.

61. Instituto Nacional de Salud. Boletin epidemiologico. Retrieved April 22, 2016, fromhttp://www.ins.gov.co/boletin-epidemiologico/ Paginas/default.aspx.
62. Von Renesse A, Schildgen O, Klinkenberg D, et al. Respiratory syncytial virus infection in children admitted to hospital but ventilated mechanically for other reasons. J Med Virol 2009; 81: $160-166$.

63. Chi H, Chang IS, Tsai FY, et al. Epidemiological study of hospitalization associated with respiratory syncytial virus infection in Taiwanese children between 2004 and 2007. J Formos Med Assoc 2011; 110: 388-396.

64. Svensson C, Berg K, Sigurs N, Trollfors B. Incidence, risk factors and hospital burden in children under five years of age hospitalised with respiratory syncytial virus infections. Acta Paediatr 2015; 104: 922-926.

65. Haynes LM. Progress and challenges in RSV prophylaxis and vaccine development. J Infect Dis 2013; 208: S177-S183.

66. Tulloh R. Etiology, diagnosis, and pharmacologic treatment of pediatric pulmonary hypertension. Paediatr Drugs 2009; 11: 115-128.

67. Medrano Lopez C, Garcia-Guereta Silva L, Lirio Casero J, Garcia Perez J. Respiratory infections, Down's syndrome and congenital heart disease: the CIVIC 21 study. An Pediatr (Barc) 2009; 71: $38-46$.

68. Chew FT, Doraisingham S, Ling AE, Kumarasinghe G, Lee BW. Seasonal trends of viral respiratory tract infections in the tropics. Epidemiol Infect 1998; 121: 121-128.

69. Lapena S, Robles MB, Castanon L, et al. Climatic factors and lower respiratory tract infection due to respiratory syncytial virus in hospitalised infants in northern Spain. Eur J Epidemiol 2005; 20: 271-276.

70. Yusuf S, Piedimonte G, Auais A, et al. The relationship of meteorological conditions to the epidemic activity of respiratory syncytial virus. Epidemiol Infect 2007; 135: 1077-1090.

71. Carpenter TC, Stenmark KR. Predisposition of infants with chronic lung disease to respiratory syncytial virus-induced respiratory failure: a vascular hypothesis. Pediatr Infect Dis J 2004; 23: S33-S40.

72. Tulloh R, Flanders L, Thompson L, Feltes T. Does RSV infection cause pulmonary hypertension in children undergoing cardiac surgery? Arch Dis Child 2011; 96: A37-A38.

73. Ram G, Chinen J. Infections and immunodeficiency in Down syndrome. Clin Exp Immunol 2011; 164: 9-16.

74. Friedman D, Wong P, Fryzek J, et al. Respiratory syncytial virus hospitalization risk in the second year of life by condition in children with congenital heart disease. Pediatric Academic Societies Annual Meeting, April 30 to May 3, 2016, Baltimore.

75. Wang D, Li A, Paes B, Mitchell I, Lanctôt K. Comparison of firstand second-season palivizumab prophylaxis in patients with congenital airway anomalies (CAA) in the CARESS database (2005-2015). International Society for Pharmacoeconomics and Outcomes Research 21st Annual International Meeting, May 21-25, 2016, Washington, DC.

76. Scaparrotta A, Attanasi M, Di Pillo S, Chiarelli F. Pediatric lower respiratory infections. OMICS Group. Retrieved October 22, 2016, from http://www.esciencecentral.org/ebooks/pediatric-lower/pdf/ Pediatric-Lower-respiratory-infections.pdf. 